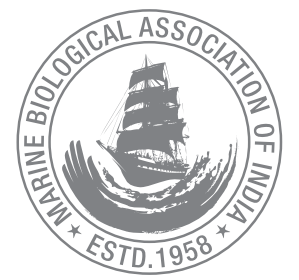

\title{
Influence of certain environmental parameters on mass production of rotifers: A review
}

\author{
Loveson L. Edward ${ }^{1 *}$, P. Laxmilatha ${ }^{2}$, K. Sreeramulu ${ }^{3}$, L. Ranjith ${ }^{4}$ and Sekar Megarajan ${ }^{1}$ \\ ${ }^{1}$ Regional Centre of ICAR-Central Marine Fisheries Research Institute, Visakhapatnam-530 003, India. \\ ${ }^{2}$ ICAR-Central Marine Fisheries Research Institute, Kochi- 682 018, Kerala, India. \\ ${ }^{3}$ Department of Zoology, Andhra University, Visakhapatnam- 530 003, India. \\ ${ }^{4}$ Research Centre of ICAR-Central Marine Fisheries Research Institute, Tuticorin-628 001, Tamil Nadu, India. \\ *Correspondence e-mail : loveson_edward@yahoo.co.in
}

Received: 01 Aug 2019 Accepted: 25 July 2020 Published: 30 July 2020

Original Article

\begin{abstract}
Larviculture of many finfishes and crustaceans in aquaculture depends mainly on the live feed and its unavailability in sufficient quantity is hampering its expansion and culture progress all around the world. The most suitable feed for marine finfish larvae is the commonly available zooplankton species such as rotifer, copepods and Artemia nauplii. Among all, the live feed that has been demonstrated more successfully as the first feed for most of the marine finfish species is rotifer. Optimum conditions are required for better growth, reproduction and increased productivity of rotifers. The major factors that influence the population size of rotifer are temperature and salinity. Hence, the impact of environmental parameters with special focus on the salinity and temperature on the increase in biomass and smaller rotifer production is of utmost importance in the present scenario.
\end{abstract}

Keywords: Live feed, larviculture, zooplankton

\section{Introduction}

The key of any aquaculture operation is larviculture of fishes and it depends mainly on the timely availability of appropriate size live feeds. In the advent of expanding culture, the progress of successful larviculture of marine finfishes is the major bottleneck. The use of artificial diets as the first feed on larvae does not yield the desired results due to the poor enzymatic activity of larvae and the absence of fully functional stomach (Pedersen and Hjelmeland, 1988). Efforts are being taken by aquaculturists to develop a formulated diet, which is easily digestible and non-polluting nature. In this context, hatchery operators are mainly depending on live feed to carry forward the larval rearing operations. Among the live feeds, the most commonly used starter feeds for larviculture of marine finfishes are Brachionus plicatilis and B. rotundiformis (Lubzens et al., 1989). The major problems persisting in mass production are the unpredictability of desired quantities, size groups and the quality of rotifer which hinders the progress of its expansion. In recent years, by manipulating environmental parameters various efforts are being undertaken to mass produce and to improve its nutritional quality. In this view, this paper insight the influence of major environmental parameters on the mass production of rotifers.

\section{Why Rotifers?}

The rotifers are preferred as an essential live food source because of their shape, size and slow moving nature which make the small larvae to easily prey on these organisms. Besides, its 
nutritional composition can be either enhanced or manipulated to pass on the required nutrition to the cultured larvae. The experimental results of Markridis et al. (2000) showed that rotifers can be used for transferring probiotic bacteria to fish larvae. Lubzens et al. (2001) opined that it can be used for transferring medicinal and therapeutic agents to the fish larvae.

\section{Mass culture techniques}

The need for rotifers are rapidly increasing and hence several mass culture techniques have been developed for multiplication of rotifers (Fukusho, 1989). The most common type of rotifer production system in marine fish hatcheries is the batch culture method (Snell, 1991) due to its simplified and ease in the methodology. The batch culture technique involves using a part of the harvest for feeding fish larvae and the rest is used as inoculums for continuing the next batch of culture (Lubzens, 1987; Dhert, 1996; Odo et al., 2015). Lubzens (1987) maintained a low density rotifer culture with an inoculation density between $50-200$ individual's $\mathrm{ml}^{-1}$ to reach a final density of 300 to over 1000 individual's $\mathrm{ml}^{-1}$ in $3-7$ days, using microalgae and/or baker's yeast as food. However, studies by Suantika et al.(2000) revealed that feeding an artificial diet (Culture Selco $\left.{ }^{\circledR}\right)$ with an initial density starting from 200 to 250 rotifer ml$^{-1}$ achieved a final harvest of about 600 rotifers $\mathrm{ml}^{-1}$ in 4 days culture. Kailasam et al. (2015) has also described a high density culture methodology, in which they used the same artificial diet and harvested up to $2,000-5,000$ rotifers $\mathrm{ml}^{-1}$ with an initial inoculum of 300-500 rotifers $\mathrm{ml}^{-1}$ in a culture period of 8 - 10 days.

The rotifer can fed with microalgae individually or in combination of two or more species or group. However, the nutritional quality of cultured rotifers depends on the transfer of dietary compounds from algae or yeast to the rotifers (Kalidoss et al., 2017). Microalgal diets such as Nannochloropsis, Isochrysis and Chlorella reveals that there is an increase in neutral lipid and phospholipid content. Fernandez-Reiriz et al.(1989) opined that Isochrysis galbana was found to contain substantial amounts of DHA and a low EPA content, whereas Sukenik et al. (1993) found Nannochloropsis gaditana contained substantial amounts of EPA. Rotifers were fed with a locally isolated microalgal strain Nannochloropsis were capable of achieving a mean production of $186.71 \times 10^{6}$ individuals $\mathrm{m}^{-3}$ day $^{-1}$ of L-type rotifers and $308.75 \times 10^{6}$ individual's $\mathrm{m}^{-3}$ day $^{-1}$ of S-type rotifers in the fibreglass tanks culture system of 1000 litre capacity (James and Abu-Rezeq, 1989).

The present trend in mass production of rotifers for aquaculture is the use of high quality and high-density biomass input as a means to increase maximum production and hence a continuous system with more sophisticated methods such as mechanization with further emphasis on automation has been developed (Abu-Rezq et al., 1997; Kailasam et al., 2015). In these improved techniques all the physicochemical parameters are maintained in optimum condition with a steady supply of microalgae. An ultra-high density mass culture of rotifers on algae was the need of the hour; Yoshimura et al. (1996) done the preliminary work on it and mass culture of rotifers using artificial diets (Suantika et al., 2000) was also carried out. With ultra high density rotifer production systems using algal paste, one can achieve mass production of rotifers with less space and manpower when compared to conventional production systems (Kailasam et al., 2015).

\section{Key physicochemical parameter's for mass culture of rotifers}

Among the various major physicochemical parameters (temperature, salinity, $\mathrm{pH}$, dissolved oxygen and ammonia) required for the lucrative growth of rotifer, the temperature and salinity have variable effects on the productivity of different strains of rotifers (Miracle and Serra, 1989; Serrania-Soto et al., 2011). The optimum environmental conditions favour higher production and unfavourable conditions keep the specific growth rate of a rotifer constant. The growth rate under favourable conditions is the maximum and is characteristic of a particular population structure. In addition, the reproductive potential of the individual strain decides the mass production of rotifers. As most of the marine finfish larvae need rotifer of smaller size groups as a first feed (Gopakumar et al., 2013), the mass production of the rotifer with special emphasis on its size groups is a major concern.

\section{Influence of temperature}

Among these environmental factors, temperature plays a vital role in the reproduction of rotifers. The marine rotifer, $B$. plicatilis is a euryhaline group and it is most productive at lower temperatures while $B$. rotundiformis adapts to high temperature condition (Fukasho, 1983). B. plicatilis and $B$. calyciflorus are the most studied species to determine the relationship between reproductive potential ( $r$ ) and temperature under controlled conditions. The reproductive potential of different strains of these species has a maximum ' $r$ ' values at different temperatures (Ignacio and Martinez, 1998). Snell (1986) also studied and they concluded that temperature has a significant influence on the reproduction of $B$. plicatilis. Pascual and Yufera (1983) recorded a highest ' $r$ ' value of 1.35 at the temperature of $35^{\circ} \mathrm{C}$ followed by 1.10 at $30^{\circ} \mathrm{C}$ (Snell, 1986) and the lowest reported ' $r$ ' value of 0.12 was noted at $10^{\circ} \mathrm{C}$ (Hirayama and Kusano, 1972). Likewise, Hagiwara et al. (1995) studied the influence of temperature on the reproductive potential of $B$. rotundiformis 'S' type and $B$. rotundiformis 'SS' and recorded the highest and the lowest ' $r$ ' 
values of 0.77 and 0.54 at $30^{\circ} \mathrm{C}$ and $25^{\circ} \mathrm{C}$ respectively. The highest ' $r$ ' value of 2.19 for $B$. rotundiformis 'ss' type was recorded at $30^{\circ} \mathrm{C}$ and the lowest value of 0.40 at $19^{\circ} \mathrm{C}$ ( $\mathrm{Su}$ et al., 1997). Starkweather (1987) investigated the influence of temperature on the reproductive potential of $B$. calyciflorus. Similarly, for B. dimidiatus, B. angularis and Keratella cochlearis were studied by Pourriot and Rougier (1975) and Walz (1983) respectively for the relationship between the temperature and the reproductive potential. Kandasami et al. (1998) opined that high temperature reduces the length, width and DLS (distance between lateral spines) of the rotifer. The size of the rotifers is bigger (130-240 $\mu \mathrm{m}$ in length) at low temperature (below $\left.20^{\circ} \mathrm{C}\right)$ and smaller $(100-210 \mu \mathrm{m})$ at higher temperatures.

\section{Influence of salinity}

Salinity plays an important role in the distribution of rotifer in nature (Mustahal et al., 1991; Joshi, 1998). However, several species can tolerate a wide range of salinity (eg. $B$. plicatilis from 1 to $97 \mathrm{ppt}$ ); but its optimal growth and reproduction were observed at salinities below 35 ppt (Lubzens, 1987). Like temperature, salinity also plays a vital role in the reproductive potential of an individual rotifer. Salinity directly influences the osmotic regulation capacity of an individual species which in turn strongly relates to the genotype and the species. Nevertheless, studies on salinity effects on rotifer individuals or populations are extremely scarce (Miracle and Serra, 1989). However, a study by Kabay and Gilbert (1978) had concluded that several freshwater rotifers are also salt tolerant to a certain extent. Few species of rotifers belonging to the genus Brachionus have been studied to determine the relationship between the salinity and ' $r$ ' under controlled laboratory conditions. Experimental studies were carried out by various workers on the species such as $B$. dimidiatus, B. plicatilis and B. rotundiformis (Pourriot and Rougier, 1975; Snell, 1986; Pascual and Yufera, 1983; Lubzens et al., 1985; Su et al., 1994; Hagiwara et al., 1995; Gopakumar, 1998; Assavaaree et al., 2003) which are halobiont species and can withstand a wide range of salinities. Studies on the reproductive potential of $B$. plicatilis have found that the highest ' $r$ ' value was recorded at the salinity of $10 \mathrm{ppt}$ to $20 \mathrm{ppt}$ and above or below this salinity the ' $r$ ' value had deviated from its mean value (Roa, 1992). The best salinity to obtain the maximum ' $r$ ' value for B. plicatilis was at $19 \mathrm{ppt}$ and $17 \mathrm{ppt}$ was reported by Ito (1960) and Lubzens (1987), respectively. However, according to Snell (1986), the optimum salinity for the highest ' $r$ ' value for B. plicatilis was noted at $30 \mathrm{ppt}$. All these studies had revealed that different clones of $B$. plicatilis have different $r$-max values at different salinities.

B. rotundiformis is best adapted to low saline conditions (Fukasho, 1983). The influence of salinity on the reproductive potential of $B$. plicatilis, B. rotundiformis ' $S$ ' type and B. rotundiformis 'SS' type was examined by Hagiwara et al. (1995). The best salinity for the maximum reproductive rate of $B$. plicatilis, $B$. rotundiformis 'S' and 'SS' type were at $11 \mathrm{ppt}(\mathrm{r}=0.49), 11 \mathrm{ppt}$ $(r=1.37)$ and 11 and $22 \mathrm{ppt}(r=1.57$ and 1.37$)$, respectively. Rotifer size was also found inversely proportional to increasing salinities in the culture system. Kandasami et al. (1998) opined that the distance between the median spines (DMS) changes with salinity. The relationship of the r-max of $B$. rotundiformis 'ss' type with five salinity levels, ranging from $5 \mathrm{ppt}$ to 30 ppt was studied by Su et al. (1994). They found the optimum culture conditions for 'ss' type was at a salinity of $10 \mathrm{ppt}$ to 20 ppt and temperature of $30^{\circ} \mathrm{C}$ to $33^{\circ} \mathrm{C}$. Pourriot and Rougier (1975) studied the relationship between the ' $r$ ' and salinity in $B$. dimidiatus. According to them, the highest reproductive output of this rotifer was noted at the salinities of $2 \mathrm{ppt}(\mathrm{r}$ $=0.429)$ and $19 \mathrm{ppt}(r=0.424)$. Thus different species or strains will have different ' $r$ ' maxima at various temperatures and salinities mainly due to species / strain collection location and its environmental parameter adaptation.

\section{Other parameters}

Apart from the key physicochemical parameters such as temperature and salinity, other factors which have a certain influence on mass production of rotifer are $\mathrm{pH}$, dissolved oxygen and ammonia (Dhert, 1996). Aeration and dissolved oxygen are one of the prime factors in rotifer culture. Although rotifers can survive in dissolved oxygen levels of $2 \mathrm{mg} \mathrm{L}^{-1}$ (Table 1), for

Table 1. Optimal conditions for culture of rotifers (modified Dhert, 1996)

\begin{tabular}{|c|c|c|c|}
\hline Parameters & Range & Optimum & \\
\hline Temperature $\left({ }^{\circ} \mathrm{C}\right)$ & $26-34$ & $28-30$ & $\begin{array}{l}\text { Rotifers reared at higher temperatures within their optimum range } \\
\text { had better growth and increased productivity. }\end{array}$ \\
\hline Salinity $\left(\mathrm{gL}^{-1}\right)$ & 1 to 97 (depends on species) & 25 to 30 (for marine species) & $\begin{array}{l}\text { Better to rear them in salinity ( } \pm 5 \mathrm{ppt} \text { ) closer to the larval rearing } \\
\text { tanks. }\end{array}$ \\
\hline Dissolved Oxygen $\left(\mathrm{mgL}^{-1}\right)$ & 2 to 5 & $>4$ & $\begin{array}{l}\text { Mild aeration is enough for mixing. Strong aeration leads to physical } \\
\text { damage to rotifers. }\end{array}$ \\
\hline $\mathrm{pH}$ & 7.5 to 8.5 & 8.0 to 8.3 & The ammonia levels are influenced by the temperature and the $\mathrm{pH}$ of \\
\hline Total Ammonia $\left(\mathrm{mgL}^{-1}\right)$ & $<1$ & $<0.5$ & $\begin{array}{l}\text { the water. High levels of un-ionized ammonia in the rearing } \\
\text { conditions are toxic to rotifers. }\end{array}$ \\
\hline Illumination & \multicolumn{2}{|c|}{ No need of separate light, natural day light enough } & Avoid direct sunlight. It may promote filamentous algal growth. \\
\hline
\end{tabular}


optimum growth and multiplication the dissolved oxygen level should be maintained above 4 ppm (Fulks and Main, 1991). Aeration should be mild and enough for mixing the water; strong aeration may cause physical damage to rotifers. The $\mathrm{pH}$ of the culture system plays an important role as the $\mathrm{pH}$, along with temperature and salinity highly influences ammonia levels and its toxicity (Bower and Bidwell, 1978). In culture conditions, better results are obtained with $\mathrm{pH}$ levels between 7.5 to 8.5. High levels of total ammonia in the rearing conditions are toxic to rotifers but optimal level of $<1 \mathrm{mg} \mathrm{L}^{-1}$ of ammonia and the acceptable range $6-10 \mathrm{mg} \mathrm{L}^{-1}$ for ammonia and nitrate levels appear to be safe (Lubzens and Zmora, 2003). Use of ozone reduced ammonia, nitrite and nitrate levels by $67 \%$, $85 \%$ and $67 \%$ respectively and the number of bacteria are found to be extremely useful in the mass culture of $B$. plicatilis (Suantika et al., 2001).

Organic waste accumulation by surplus food should be avoided in the rotifer culture tanks. It indirectly affects the physicochemical parameters and supports bacterial growth (Lubzens and Zmora, 2003). Not all bacteria are pathogenic to rotifers. Multiplication of harmful pathogenic bacteria should be avoided in the interest of rotifer and its feeding fish larvae (Dhert, 1996). An effective way to control the unwanted pathogenic bacteria counts is by feeding the rotifers with probiotics (Markridis et al., 2000). A probiotic combination containing beneficial bacteria such as Bacillus, Thiobacillus, Acetobacter and Paracoccus when supplemented with enzymes, was found to be more effective in the competitive elimination of Vibrios in rotifer mass culture tanks (Loka et al., 2016). This probiotic supplementation of beneficial bacteria has not only regulated the microfloral content but also enhanced the rotifer density and mass production. The occurrence of ciliates is generally considered as contamination, affects rotifers due to competition for food. The metabolic wastes of ciliates increase the $\mathrm{NO}_{2}-\mathrm{N}$ level in the water. Simple screening and cleaning of the rotifers by passing through $<40 \mu \mathrm{m}$ mesh reduces the number of ciliates and other contaminants (Dhert, 1996).

\section{Conclusion}

B. plicatilis and $B$. rotundiformis are more tolerant of temperature and salinity fluctuations (Kandasami et al., 1998). Such cultured live feed, especially rotifers, should satisfy the larval feeding purpose. The majority of the fish larvae with small mouth gape lack perceptive powers for searching external feed (Gopakumar et al., 2013). The size of the feed is important when the mouth size of the larvae is concerned (Santhosh and Anil, 2013). A suitable sized, nutritionally enriched live food organism is the major requirement for the mass rearing of many finfish larvae. To develop mass culture methods for the potential rotifer species, a controlled condition is necessary for a specific species. The environmental variables like temperature and salinity play a key role in developing a mass culture of rotifers. Thus, more understanding of the effect of these parameters on the growth and reproductive performance is very much essential to improve culture and nutritional quality of the rotifer species. Since seed production and culture practices of several marine finfishes such as Cobia, Silver pompano, Orange spotted grouper, Indian pompano, Tiger grouper and Pink ear emperor are taking up a major leap in the Indian aquaculture industry as an alternate species for mariculture; mass production of smaller rotifers is of utmost essential to take this technology forward.

\section{Acknowledgements}

The constant help rendered by the Scientist-in-charge, Visakhapatnam Regional Centre, ICAR-CMFRI and the Director, ICAR-CMFRI for the study is thankfully acknowledged. The constructive suggestions and valuable inputs of the advisory committee members of the Ph.D. work of the first author are also acknowledged.

\section{References}

Abu-Rezq, T., J. Al-Shimmari and P. Dias. 1997. Live food production using batch culture and chemostat system in Kuwait. Hydrobiologia, 358: 173-178.

Assavaaree, M., A. Hagiwara, T. Koyane and M. Arimote. 2003. Effect of temperature on resting egg formation of the tropical 'ss' type rotifer Brachionus rotundiformis Tschugunoff. Fisheries Science, 69: 520 -528.

Dhert, P. 1996. Rotifers. In: Lavens, L and Sorgeloos, P. (Eds), Manual on the production and use of live food for aquaculture, Food and Agriculture Organization, Rome, p. 49-78.

Fernandez-Reiriz, M. J., A. Perez-Camacho, M. J. Ferreiro, J. Blanco, M. Planas, M. J. Campos and U. Labarta. 1989. Biomass production and variation in the biochemical profile (total protein, carbohydrates, RNA, lipids and fatty acids) of seven species of marine microalgae. Aquaculture, 83 (1-2): 17-37.

Fukasho, K. 1983. Present status and problem in culture of the rotifer Brachionus plicatilis for fry production of marine fishes in Japan. Symposium. International de Aquaculture coquimbo, Cheke-Septiebre, p. 361-373.

Fukusho, K. 1989. Biology and mass production of the Rotifer Brachionus plicatilis. Int. J. Aq. Fish. Technol., 1: 232-240.

Fulks, F. and K. L. Main. 1991. Rotifer and microalgae culture systems. Proc. US-Asia Workshop, Oceanic Institute, Honolulu, HI, 364 pp.

Gopakumar, G. 1998. Studies on brackishwater rotifers of Kerala with special reference to Brachionus plicatilis O. F. Muller as live feed for aquaculture. Ph. D. thesis, University of Kerala

Gopakumar, G., A. K. A. Nazar and R. Jayakumar. 2013. Live feed culture and larval rearing of marine finfishes. In. Imelda, J and Edwin, J (eds) Customized Training in Mariculture for Maldivian Officials. Central Marine Fisheries Research Institute, Kochi. p. 85 - 93.

Hagiwara, A., T. Kotani, T. W. Snell, M. Assava-Aree and K. Hirayama.1995. Morphology, reproduction, genetics and mating behavior of small tropical marine Brachionus strains (Rotifera). J. Exp. Mar. Bioi. Ecol., 194: 25-37.

Hirayama, K. and T. Kusano. 1972. Fundamental studies on physiology of rotifer for its mass culture-II. Influence of water temperature on population growth of rotifer. Bull. Jap. Soc. Sci. Fish., 38: 1357-1363.

Ignacio, A. P. and R. R. Martinez.1998. Effect of temperature and food concentration in two species of littoral rotifers. Hydrobiologia, 387/388: 341-348

Ito, T. 1960. On the culture of mixohaline rotifer Brachionus plicatilis O. F. Muller in seawater. Rep. Fac. Fish. Perfect. Unive. Mie., 3: 708 -740.

James, C. M. and A. T. S. Rezeq. 1989. An intensive chemostat culture system for the production of rotifers for aquaculture. Aquaculture, 81: 291-301.

Joshi, P. S. 1988. Influence of salinity on population growth of a rotifer, Brachionus plicatilis(Mullen). J. Ind. Fish. Assoc., 18: 75-81. 
Kabay, M. E. and J. J. Gilbert.1978. Polymorphism in the rotifer Asplanchna sieboldi: intensity of the body wall outgrowth responses to temperature, food density, $\mathrm{pH}$ and osmo-regularity differences. Arch. Hydrobiol., 83: 377-390.

Kailasam, M., A. R. Thirunavukkarasu, A. G. Ponniah, S. Selvaraj and P. Stalin. 2015. Recent advances in rotifer culture and its application for larviculture of finfishes. In: Perumal, S., A. R. Thirunavukkarasu and P. Pachiappan. (Eds). Advances in Marine and Brackishwater Aquaculture. Springer, p. 17 -23.

Kalidoss, R., S. Aanand, S. Rameshkumar and F. Divya. 2017. Effect of feeding rate and feeding frequency in mass culture of Brachionus plicatilis in semi-continuous method with a yeast-based diet. J. Fish. Life Sci., 2(1): 40-44.

Kandasami, D., S. Palanichamy and S. Mohan.1998. Techniques for the mass culture of rotifers and moina. In: Proceedings of the Workshop National Aquaculture Week. The Aquaculture Foundation of India, Chennai, p. 82-85.

Loka, J., S. M. Sonali, P. Saha, K. Devaraj and K. K. Philipose. 2016. Use of commercial probiotics for the improvement of water quality and rotifer density in outdoor mass culture tanks. Indian Journal of Fisheries, 63 (4): 145-149.

Lubzens, E. 1987. Raising rotifers for use in aquaculture. Hydrobiologia, 147: 245-255.

Lubzens, E., A. Tandler and G. Minkoff. 1989. Rotifers as food in aquaculture. Hydrobiologia, 186/187: 387-400.

Lubzens, E. and O. Zmora.2003. Production and nutritional value of rotifers. In: Live feeds in marine Aquaculture, Blackwell science, Oxford, U.K. p.17-64.

Lubzens, E., O. Zmora and Y. Barr. 2001. Biotechnology and aquaculture of rotifers. Hydrobiologia, 446/447: 337-353.

Lubzens.E., G. Minkoff and S. Marom.1985. Salinity dependence of sexual and asexual Reproduction in the Rotifer, Brachionus plicatilis. Mar. Biol., 85: 123-126.

Markridis, A., A. J. Fielheim, J. Skjermo and A. Vadstein. 2000. Control of bacterial flora of Brachionus plicatilis and Artemia franciscana by incubation in bilateral suspensions. Aquaculture, 185: 207-218.

Miracle, M. R. and M. Serra. 1989. Salinity and temperature influence in rotifer lifehistory characteristics. Hydrobiologia, 186/187: 81-102.

Mustahal, S. Yamasaki and H. Hirata. 1991. Salinity adaptability of five different strains of the rotifer Brachionus plicatilis. Bull. Jap. Soc. Sci. Fish., 57: 1997-2000.

Odo, G. E., J. E. Agwu, F. O. Iyaji, J. C. Madu, N. I. Ossai and L. N. Allison. 2015. Mass production of rotifer (Branchionus calyciflorus) for aquaculture in southeastern Nigeria. Int. J. Fish. Aquac., 7: 151-159.

Pascual, E. and M. Yufera. 1983. Crecimientoencultivo de unacepa de Brachionus plicatilis O. F. Muller enfunction de la temperature y la salinidad. Invest. Pesq., 47: 151-159.

Pedersen, B. H. and K. Hjelmeland.1988. Fate of trypsin and assimilation efficiency in herring Clupea harengus L. following digestion of copepods. Mar. Biol., 97: 467-476.
Pourriot, R. and C. Rougier. 1975. Dynamiqued'une population experimentale de Brachionus dimidiatus (Bryce) (Rotiferes) enfunction de la nourriturest de la temperature. Anns. Limnol., II : 125-143.

Roa, R. T. 1992. Biological observations in a stock of the rotifer Brachionus plicatilis isolated from the solar salt paos of Araya, Venezuela. Bol. Inst. Oecanogra. Venez., 32(1): 51-61.

Santhosh, B. and M. K. Anil. 2013. Zooplankton for marine fish larval feed. In. Imelda, $\mathrm{J}$ and Edwin, J (eds) Customized Training in Mariculture for Maldivian Officials. Central Marine Fisheries Research Institute, Kochi. p. 140 - 143

Serrania-Soto, C.R., S. S. S.Sarma and S. Nandini.2011. Studies on comparative population growth of some species of the rotifer Lecane (Rotifera). J. Environ. Biol. 32(4):523-527.

Snell, T. W. 1986. Effect of temperature, salinity and food level on sexual and asexual reproduction in Brachionus plicatilis (Rotifera). Mar. Biol., 92: 157-162.

Snell, T. W. 1991. Improving the design of mass culture systems for the rotifer, Brachionus plicatilis. In: Fulks, W., Main, K.L. (Eds.), Rotifer and Microalgae Culture Systems. Proceeding of US-Asia Workshop, Honolulu, Hawai, Jan. 28-31, p. 61-71.

Starkweather, P. L. 1987. Rotifer energetics.In: Animal energetics, Vol.1. (ed. Pandian, T. J. and Vernberg, S. J.), Academic press, p. 159-183.

Su, H. M., M. S. Su and I. C. Liao.1994. Selection of super smail-sized strain of rotifer (Brachionus plicatilis) and its rearing conditions. J. Taiwan Fish. Res., 2 (1): 19-29.

Su, H. M., M. S. Su and I. C. Liao.1997. Collection and culture of live foods for aquaculture in Taiwan. Hydrobiologia, 358: 37-40.

Suantika, G., P. Dhert, G. Rombaut, J. Vandenberghe, T. De Wolf and P. Sorgeloos. 2001. The use of ozone in a high density recirculation system for rotifers. Aquaculture, 201, 35-49.

Suantika, G., P. Dhert, M. Nurhudah and P. Sorgeloos.2000. High-density production of the rotifer Brachionus plicatilisin a recirculation system: consideration of water quality, zootechnical and nutritional aspects. Aquacult. Eng., 21: 201-214.

Sukenik, A., O. Zmora and Y. Carmeli. 1993. Biochemical quality of marine unicellular algae with special emphasis on lipid composition of Nannochloropsis sp. Aquaculture, 117: 313-326.

Walz, N. 1983. Continuous culture of the pelagic rotifers Keratella cochlearis and Brachionus angularis. Arch. Hydrobiol., 98: 70-92.

Yoshimura, K. A., A. Hagiwara, T. Yoshimatsu and C. Kitajima.1996. Culture technology of marine rotifers and implication for intensive culture of marine fish in Japan. Mar. Freshwater Res., 47: 217-222. 